\title{
低温動作カソードにおける寿命特性および電子放射層の変化
}

\author{
杉村 俊和, 田中 義之 \\ 関西日本電気(侏)，广520-8555 大津市晴嵐 2-9-1.
}

\section{Life Characteristics and Changes in the Emitting Layer of Low Temperature Operating Cathode}

\author{
Toshikazu Sugimura and Yoshiyuki Tanaka \\ NEC Kansai, Ltd., 2-9-1 Seiran, Otsu 520-8555.
}

Received September 18, 2001

\section{SYNOPSIS}

An electron emitter pellet for low temperature operating cathode has been developed by integrating a mixture of $(\mathrm{Ba}, \mathrm{Sr}, \mathrm{Ca}) \mathrm{CO}_{3}$ powder, $\mathrm{Ni}$ powder and $\mathrm{Sc}_{2} \mathrm{O}_{3}$ powder using hot isostatic pressing (HIP). During the exhaustion process of cathode ray tube (CRT), an emitting layer composed of oxide emitter is formed on the pellet surface. During emission, this emitting layer plays an important role. In this study, we performed life tests of the pellet at high current density. Emission properties were evaluated by measuring maximum cathode currents and observing cathode images. In addition, time course changes of the emitting layer were examined. Superior life characteristics of less than $3 \%$ and $20 \%$ reduction in the maximum cathode current $1.5 \times 10^{4} \mathrm{~h}$ and $3.5 \times 10^{4} \mathrm{~h}$, respectively, after the start of the high current application life test with an average current density of $3 \mathrm{~A} / \mathrm{cm}^{2}$, ten times as large as practical current density of CRTs, were obtained. These conditions reveal that the pellet exhibits superior life properties against high current loads. The emitting layer on the pellet surface develops irregularities $1.5 \times 10^{4} \mathrm{~h}$ after the start of the life test, with a part of $\mathrm{Ni}$ exposed. The emission properties of the pellet do not deteriorate regardless of such irregularities in the emitting layer; this is considered to be because $\mathrm{Ba}$ is supplied from the inside of the pellet, and $\mathrm{BaO}$ covers the entire pellet surface.

KEY WORDS

HIP, HIP cathode, life test, cathode image, maximum cathode current, current density

\section{1 緒訔}

近年の CRT (Cathode Ray Tube) の大型化，高精細化の要求 に応えるため，著者らは比較的低い温度で高い電流密度が得 られる「低温動作HIP カソード」を開発した. 本カソードは, 従来から広く用いられている酸化物カソードの動作温度に近い $1053 \mathrm{~K}$ で, 高出力カソードとして知られる含浸形かソード ${ }^{1,2}$ のみが対応可能であった $3 \mathrm{~A} / \mathrm{cm}^{2}$ の高い出力で動作する特長が ある3-の.

本カソードにおいて電子放射を担うカソードペレットは, 電子放射材 (以下エミッ夕)である3元系炭酸塩 $(\mathrm{Ba}, \mathrm{Sr}, \mathrm{Ca}) \mathrm{CO}_{3}$ 粉末, $\mathrm{Ni}$ 粉末および $\mathrm{Sc}_{2} \mathrm{O}_{3}$ 粉末の混合粉末を HIP (Hot Isostatic Pressing)で焼結固化し，大気中で安定な Ni- 炭酸塩複合体の 状態で機械加エしてペレット化し，管球の熱分解工程で炭酸 塩を酸化物に転換した Ni-酸化物複合体である゙ .著者らは前
報のにおいて，ペレットの熱分解工程でカソードペレットを 一定の速度で加熱することにより，焼結体内に閉じ込められ ていた炭酸塩のエミッタが $\mathrm{CO}_{2}$ 放出を伴いながらペレット表 面に噴出し，酸化物エミッタからなる厚さ約 $10 \mu \mathrm{m}$ の多孔質 電子放射層が形成され，安定した高出力が得られることを明 らかにした。

本報では，低温動作 HIP カソードの高電流密度動作におけ る寿命特性を明らかにし, 長時間動作後の電子放射層の変化 を調ベた。

\section{2 実験方法}

\section{1 カソードペレットの作製}

実験に用いた $\mathrm{Ni}$ 粉末は純度 99.9 mass\% (以下 \%), 平均粒径 約 $4 \mu \mathrm{m}$ の球状粉末, エミッ夕は純度 $99.5 \%$, 平均粒径 $5.5 \mu \mathrm{m}$, 
$\mathrm{Ba}, \mathrm{Sr}, \mathrm{Ca}$ のモル比が 5:4:1の3 元系炭酸塩粉末である.また， 添加剤の $\mathrm{Sc}_{2} \mathrm{O}_{3}$ 粉末として純度 $99.9 \%$, 平均粒径約 $5 \mu \mathrm{m}$ の針 状粉末を使用した. $\mathrm{Ni}$ 粉末とエミッ夕は体積比が 1:1になる ように調合し, $\mathrm{Sc}_{2} \mathrm{O}_{3}$ は $\mathrm{Ni}$ とエミッ夕の総量に対して $2.5 \%$ 添 加した.これらの粉末を乾式でシェーカー湿合した後, CIP (Cold Isostatic Pressing)により $100 \mathrm{MPa}$ で成形した。得られた 成形体は BN 粉末を介してパイレックスガラスチューブ内に 挿入し, $10^{-3} \mathrm{~Pa}$, 約 $800 \mathrm{~K}$ でベーキングを行った後, カプセル 封止した. カプセルは温度 $1373 \mathrm{~K}$ ，圧力 $130 \mathrm{MPa}$ ，保持時間 $1 \mathrm{~h}$ の条件で HIP 焼結した. 得られた焼結体をダイサーによる湿 式切断, 湿式ラップ機による鏡面研磨の後, 打ち抜いて直径 $1.35 \mathrm{~mm}$ ，厚み $0.21 \mathrm{~mm}$ の円板形状ペレットにした.

2.2 カソードの実装, 分解および枯化処理

カソードの管球実装評価を行うために, ペレット，スリー ブおびキャップとを溶接で一体化してカソード構体を作製 した ${ }^{5)}$. カソード構体, ヒーターおよび電極 (電子レンズ)で 構成した電子銃を管球内に挿入し，排気ボンプの搭載された 排気装置(排気カート)に取り付け, 管球内が所定の真空度に 到達した時点でヒーターを点灯して炭酸塩エミッタを酸化物 に転換する分解処理のを開始した。発生する $\mathrm{CO}_{2}$ は管球外に 放出し，管球内真空度が $5 \times 10^{-3} \mathrm{~Pa}$ 程度まで回復したあと排気 管部を封じた．更に真空度を向上させるため，管球内に装着 した $\mathrm{BaAl}_{4}$ が主成分のゲッターを誘導加熱し， $\mathrm{Ba}$ 膜を管球内 に蒸着させて残留ガスを吸着するゲッターフラッシュ処理を 行い，管球内真空度を $1 \times 10^{-5} \sim 1 \times 10^{-6} \mathrm{~Pa}$ まで上昇させた. 外 部加熱による熱活性化と通電加熱による電流活性化の 2 段階 で枯化処理を行ったの。

\section{3 寿命䳝験}

\subsection{1 カソードの動作回路および試験条件}

HIP カソードの高電流密度印加での寿命特性および電子放 射層の経時変化を明らかにするために，通常の動作で必要な 平均電流密度 $0.2 \sim 0.5 \mathrm{~A} / \mathrm{cm}^{2}$ より一析大きい $3 \mathrm{~A} / \mathrm{cm}^{2}$ を負荷し て, $3.5 \times 10^{4} \mathrm{~h}$ までの長期間にわたる大電流密度加速試験を 行った. 試験にはカソードへの大電流密度の負荷が容易な動 作回路で構成した装置を用いた. 大電流密度加速試験装置の 回路図(A)を Fig.1に示す. 管球内に搭載した電子銃の電子レ

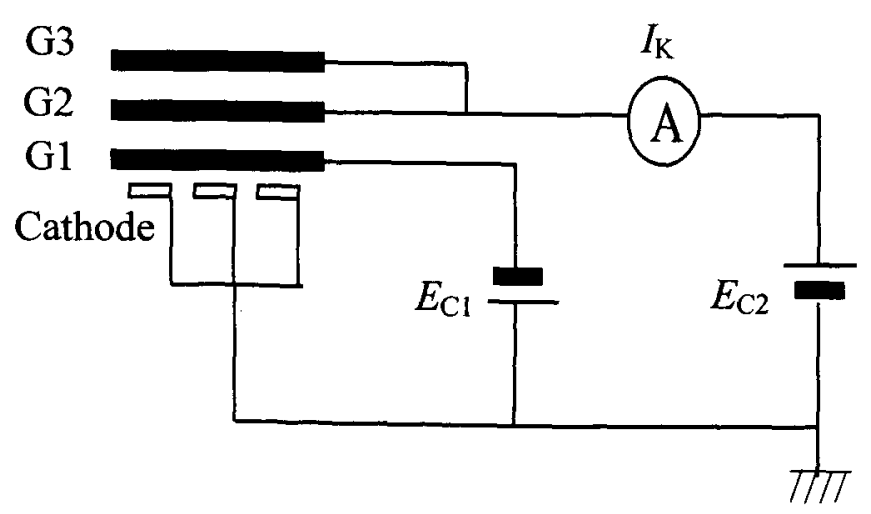

Fig.1 Circuit (A) for life test under high current density $\left(3 \mathrm{~A} / \mathrm{cm}^{2}\right)$.
ンズ群のうちカソード, 第 1 グリッド(G1) および第2グリッ ド(G2)の3 電極で動作させた. 所定のカソード電流 $I_{\mathrm{K}}$ は, 力 ソードおよび $\mathrm{G} 1$ の電圧である $E_{\mathrm{C} 1}$ を $0 \mathrm{~V}$ に固定した状態で， $\mathrm{G} 2$ 電圧である $E_{\mathrm{C} 2}$ 上界させて引き出した. 複数の寿命試験 球のうち, $1.5 \times 10^{4} \mathrm{~h}$ 経過した試験球の 1 本を用いて，試験前 のペレットの表面状態および断面の微細組織を寿命試験前と 比較検討した.

高電流密度印加での電子放射特性変化およびペレット表面 の電子放射状態の変化を調べるために, 管球の実動作条件に 近い回路にて過負荷電流加速試験を行った. 実動作過負荷加速 試験装置の回路図(B)をFig.2に示す. 所定の $I_{\mathrm{K}}$ は, $E_{\mathrm{C} 1}$ を $0 \mathrm{~V}$, $E_{\mathrm{C} 2}$ を $650 \mathrm{~V}$ に固定した状態でカソードドライフ電圧 $\left(E_{\mathrm{K}}\right)$ を上 '昇させて引き出した. HIP カソードおよひ酸化物カソードに 対して，それぞれ平均電流密度 $1.0,1.75,2.5 \mathrm{~A} / \mathrm{cm}^{2}$ を負荷し， 電子放射特性の経時変化を比較検討した。

\subsection{2 寿命特性の評価}

寿命試験時における電子放射特性の経時変化を評価した。 一定の試駼経過時間ことに管球を寿命試験装置から取出し， 最大カソード電流 $(M I k)$ を測定した. Fig.3に $M I k$ 測定装置の

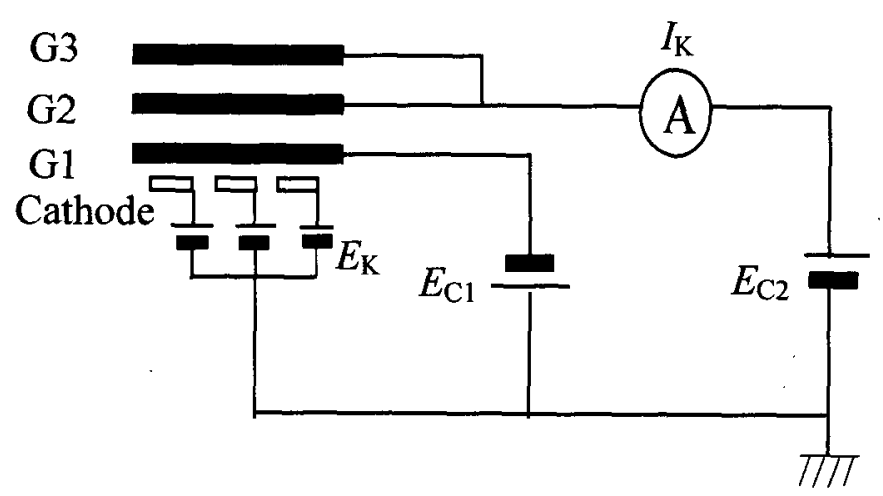

Fig.2 Circuit (B) for life test under high current density (1.0 2.5 $\mathrm{A} / \mathrm{cm}^{2}$ ).

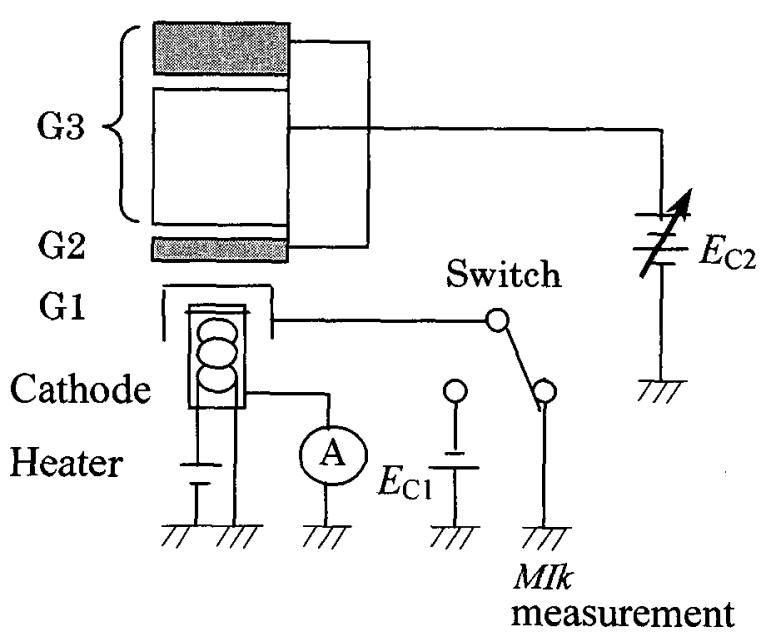

Fig.3 Schematic drawing of the experimental arrangement for maximum cathode current ( $M I k$ ) measurement. 
構成図を示す. $E_{\mathrm{C} 1}$ を $-90 \mathrm{~V}$ とした後, $E_{\mathrm{C} 2}$ を変化させて, $I_{\mathrm{K}}=$ $1 \mu \mathrm{A}$ になるように設定した. $E_{\mathrm{C} 1}$ を-90Vから $0 \mathrm{~V}$ とした時の $I_{\mathrm{K}}$ が $M I k$ 値である．また，高圧印加電源を備えた評価装置を 用いて，カソードのペレット表面における電子放射状態を管 球の蛍光面に直接投影して得られた像(以下, カソード像)に より観察した. Fig.4にカソード像観察に用いた装置の構成を 示す. 通常動作時には第4グリッド (G4)電圧である $E_{\mathrm{C} 4}$ に第 3 グリッド $(\mathrm{G} 3)$ 電圧である $E_{\mathrm{C} 3}$ の 4 倍程度の電圧を印加して電 子ビームを収束させ (Fig.4 点線部分), カソード像測定時には $E_{\mathrm{CA}}$ を $E_{\mathrm{C} 3}$ と同電位にして, 電子ビームを収束させること(Fig.4 鎖線部分)なく，そのまま赤, 緑, 青の3 原色を点状に蛍光面 上に投影させる.カリードのペレット表面の電子放射してい る部分は点状の 3 原色によって表示され，電子放射していな い部分は黒い斑点として現れるため, ペレット表面の電子放 射状態か観察できる.この像はカソードのペレット表面全体 が投影されたものでなく中央部の一部分が投影されたもので あるが，本観察によって管球内に搭載したままカソードの電 子放射状態を観察することができる，なお，本論文では 3 原 色により表示されたカソード像をモノクローム印刷している ため，赤色に映し出された部分か黒く表示されている。例え

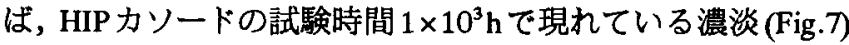
は電子放射の不完全さによるものではなく，酸化物カソードの $1 \times 10^{3} \mathrm{~h} て ゙$ 現れている黒点が電子放射していない部分を示して いる.

\section{4 微細組織の観察}

平均電流密度 $3 \mathrm{~A} / \mathrm{cm}^{2}$ の大電流密度加速試験 過した試験球を解体してカソード構体を取出し，ペレットの 微細組織観察を行った。寿命試験前後のペレット表面および ペレット断面の微細組織と元素分布はそれぞれ走查型電子顕 微鏡(SEM)およびEPMAを用いて調へた。組織観察は，断面 を研磨した後に塩化第二鉄水溶液で腐食して行った。

\section{3 実験結果および考察}

3.1 電子放射特性の経時変化

平均電流密度 $3 \mathrm{~A} / \mathrm{cm}^{2}$ を負荷した大電流密度加速試験におい

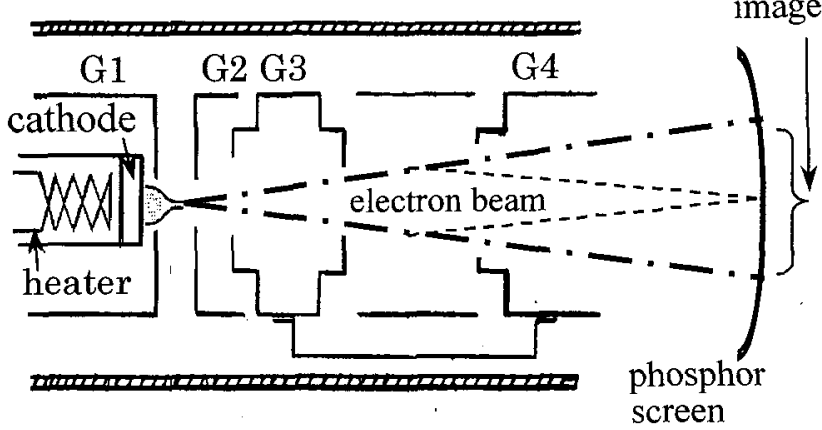

Fig.4 Schematic drawing of the experimental arrangement for cathode image measurement.
て $3.5 \times 10^{4} \mathrm{~h}$ 経過するまでの $M I k$ の経時変化を Fig.5に示す． HIP カソードの $1.5 \times 10^{4} \mathrm{~h}$ 経過時点におけるカソード電流の低 減は $3 \%$ 未満, $3.5 \times 10^{4} \mathrm{~h}$ 経過時点においても $20 \%$ 未満である. 酸化物カソードのMIkは, 約 $1 \times 10^{3} \mathrm{~h} て ゙$ 半減している.一般に, 初期のMIkが50\%低減するまでの時間の長短によってCRTの 寿命特性を判断するが, この結果から平均電流密度 $3 \mathrm{~A} / \mathrm{cm}^{2}$ の大 電流密度の負荷でも $4 \times 10^{4} \mathrm{~h}$ 以上の寿命性能が見込まれ，大き な電流負荷をカソードに要求するCRTに対して優れた寿命特 性をもつことが明らかになった。

\section{2 電子放射状態の変化}

実動作過負荷加速試験において，異なった電流密度下で動 作させたカソードをそれそれれ試験開始時 $(0 \mathrm{~h}), 400 \mathrm{~h}, 1 \times 10^{3} \mathrm{~h}$ 経過後におけるカソード温度 $\left(T_{\mathrm{K}}\right)$ に対する $M I k$ の変化および カソード像をそれぞれ Fig.6, Fig.7に示す.また，通常動作温 度 $\left(\mathrm{HIP}\right.$ カソード $T_{\mathrm{K}}=1053 \mathrm{~K}$, 酸化物カソード $T_{\mathrm{K}}=1013 \mathrm{~K}$ ) で のカソード毎の $M I k$ の $1 \times 10^{3} \mathrm{~h}$ 経過までの変化を Fig.8に示す. HIP カソードの場合, 印加された電流密度にかかわらず，400h 経過時点において通常動作温度以下でMIkの上昇が見られ， 動作初期加電子放射特性が向上している. $1 \times 10^{3} \mathrm{~h}$ 経過時点 においても全くMIkの低下が生じておらず，通常動作温度で のMIkに変化が見られない．また，カソード像にも変化が見 られず，これらの結果は，ペレット表面の電子放射が一定で あることを示している。酸化物カソードの場合, $400 \mathrm{~h}$ 経過時 点において，すでに電流密度の負荷が大きいほど顕著に $M I k$ の低隇が見られ，更に $1 \times 10^{3} \mathrm{~h}$ 経過時点では $2.5 \mathrm{~A} / \mathrm{cm}^{2}$ 負荷で 試験開始時の 60\% まで低隇している (Fig.6, Fig.8). また，力 ソード像にも大きな変化が見られ (Fig.7), 高電流負荷により $M I k$ の低滅が大きいカソードほど電子放射していない黒点の 数が增している.このことから， $1 \times 10^{3} \mathrm{~h}$ までの寿命試験にお いて，すでにペレット表面の電子放射が不均一になり，電子 放射特性が著しく低下していることが明らかである。

$2.5 \mathrm{~A} / \mathrm{cm}^{2}$ を負荷し $7 \times 10^{3} \mathrm{~h}$ まで継続させたときの $M I k$ の変 化を Fig. 9 に, $7 \times 10^{3} \mathrm{~h}$ 経過後の HIP カソードのカソード像を

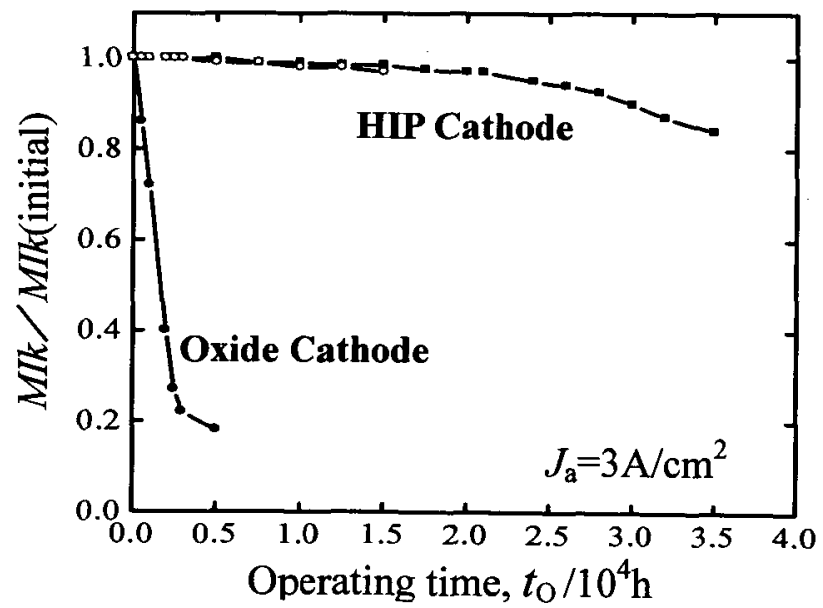

Fig.5 Life characteristic of a HIP cathode and an oxide cathode for a current density of $3 \mathrm{~A} / \mathrm{cm}^{2}$ after $3.5 \times 10^{4} \mathrm{~h}$ 

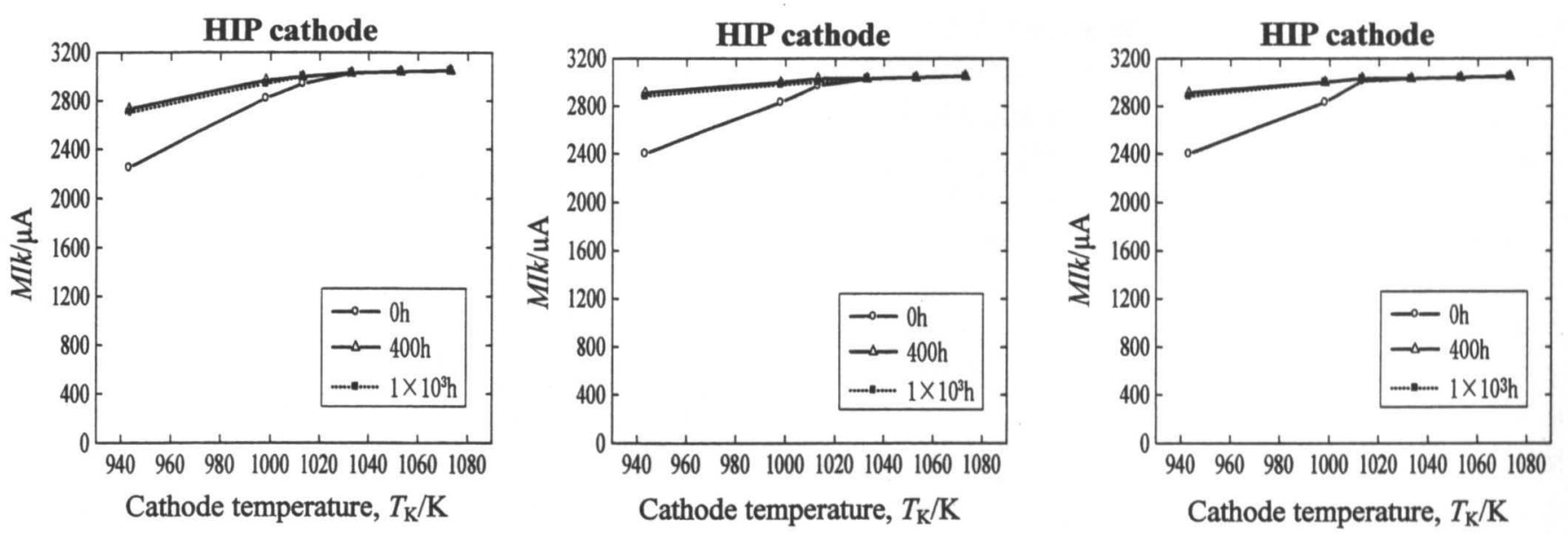

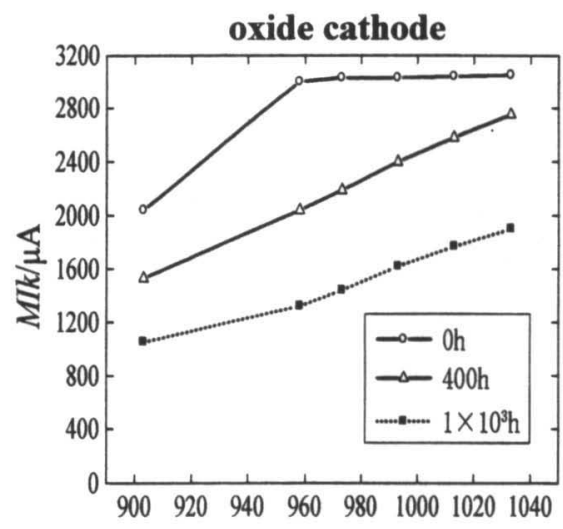

Cathode temperature, $T_{\mathrm{K}} / \mathrm{K}$

(a) $2.5 \mathrm{~A} / \mathrm{cm}^{2}$

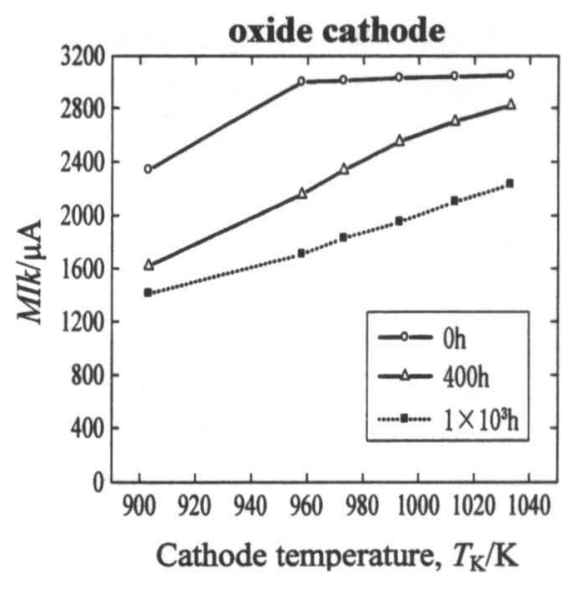

(b) $1.75 \mathrm{~A} / \mathrm{cm}^{2}$

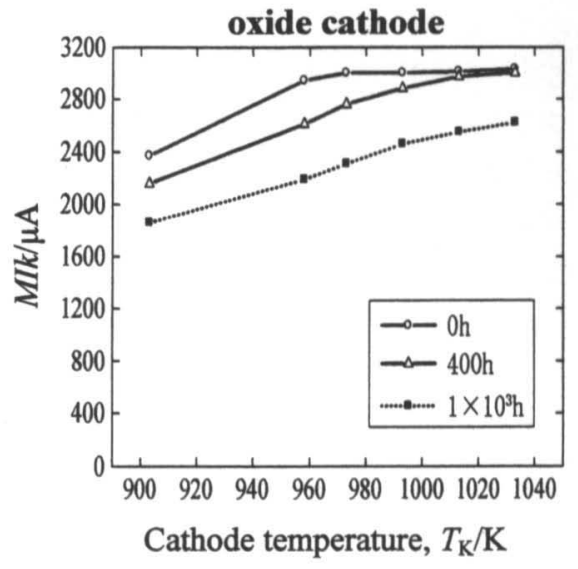

(c) $1.0 \mathrm{~A} / \mathrm{cm}^{2}$

Fig.6 Relation between maximum cathode current (MIk) and cathode temperature of HIP cathodes and oxide cathodes in life test, operating at different current density.

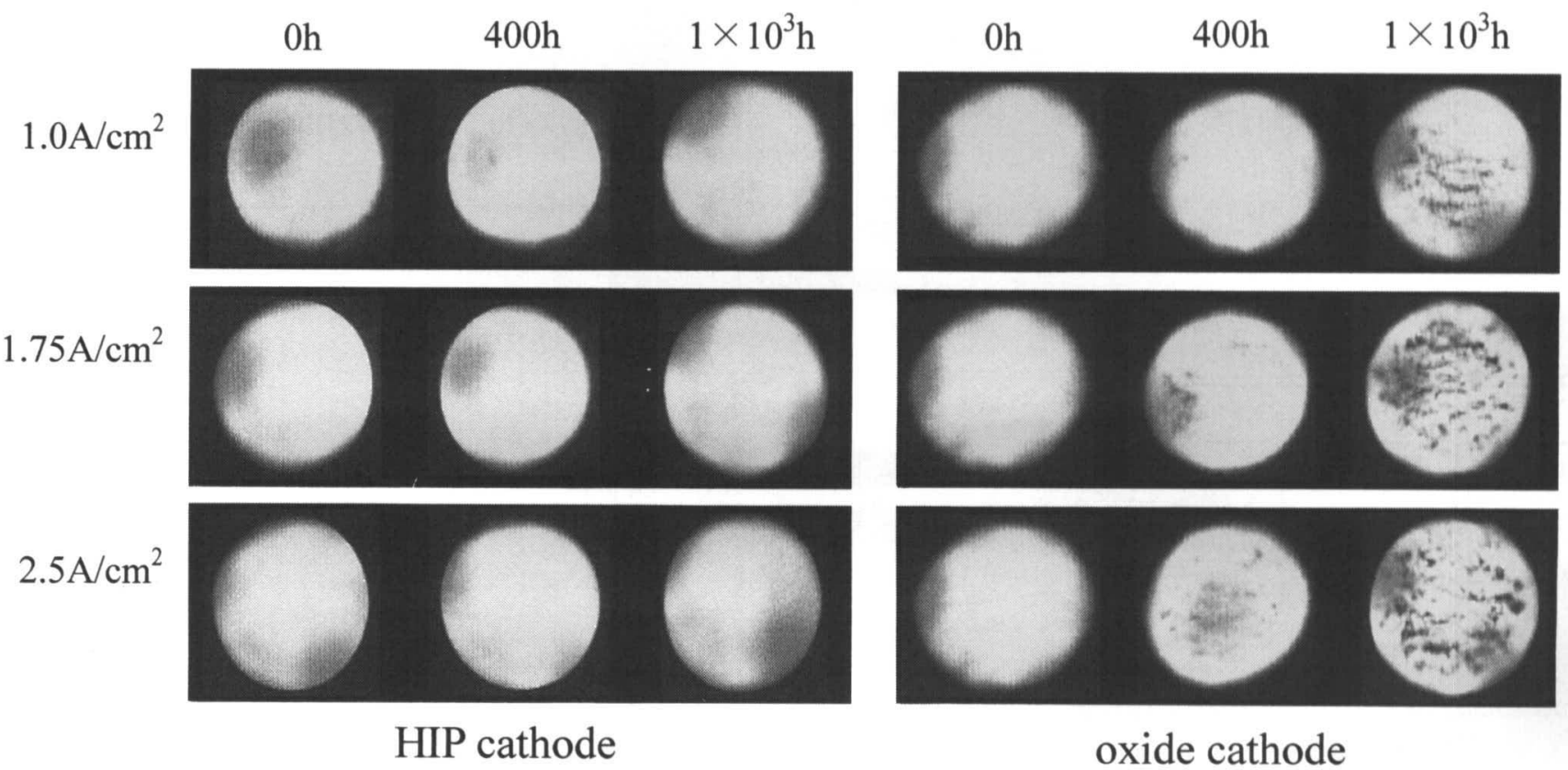

Fig.7 Photographs of cathode image of HIP cathodes and oxide cathodes in life test, operating at different current density. 


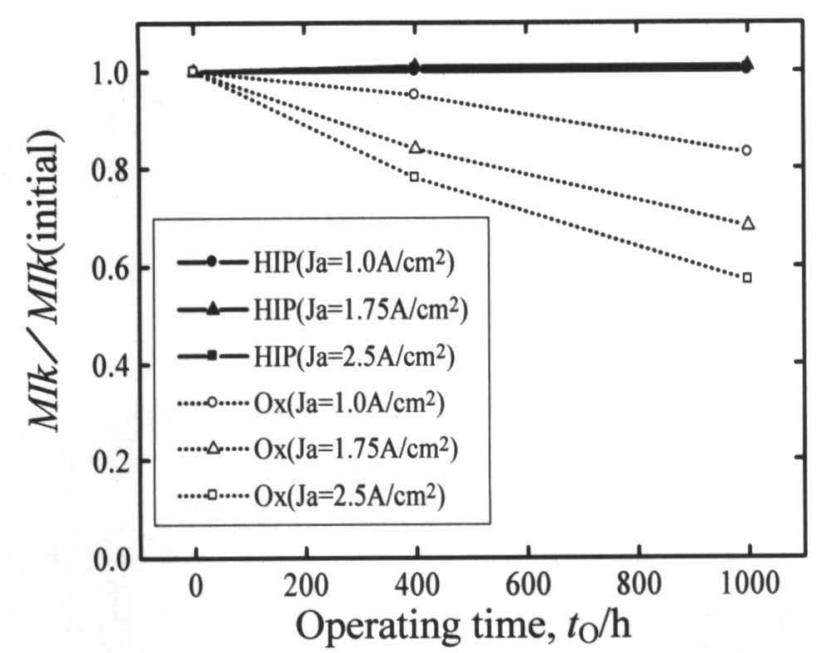

Fig.8 Life characteristic of a HIP cathode and an oxide cathode for a current density of $2.5 \mathrm{~A} / \mathrm{cm}^{2}$ after $1 \times 10^{3} \mathrm{~h}$.

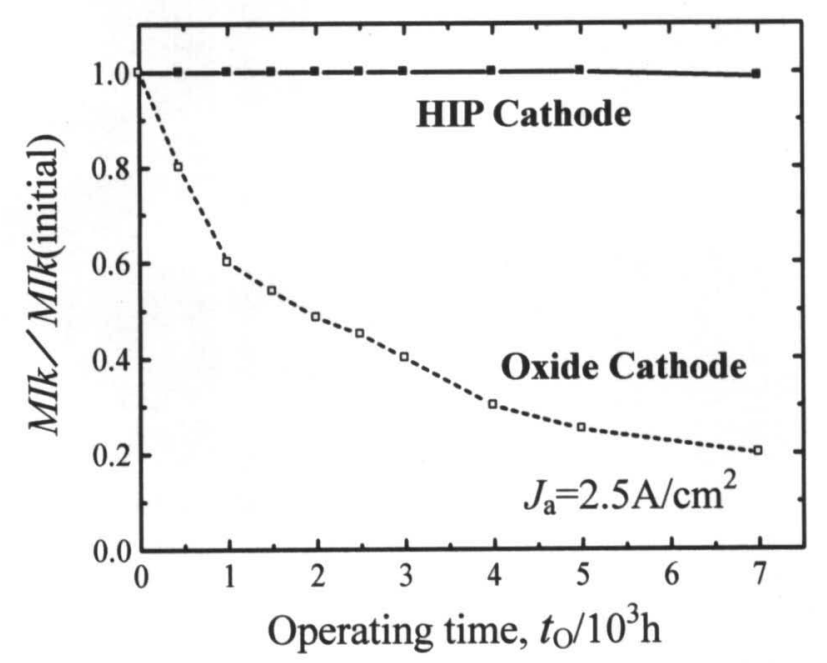

Fig.9 Life characteristic of a HIP cathode and an oxide cathode for a current density of $2.5 \mathrm{~A} / \mathrm{cm}^{2}$ after $7 \times 10^{3} \mathrm{~h}$.

Fig.10に示す. HIPカソードの場合, 全く MIkの低下が見られ ず, カソード像も動作初期 (Fig.7) 加ら変化せず, 黒点の発生 が見られない.これらの結果から, $7 \times 10^{3} \mathrm{~h}$ 経過後もペレット 表面からの電子放射の均一性が保たれ, HIP カソードが高電 流負荷に対して優れた寿命特性を有していることが明らかに なった.

3.3 電子放射層の微細組織の変化

大電流密度加速試験前および $1.5 \times 10^{4} \mathrm{~h}$ 経過後のペレット表 面のSEM写真をFig.11に, EPMA面分析の結果をFig.12に示す. また，ペレット断面の面分析の結果を Fig.13に示す. 寿命試 験前は, 前報のに示したように, ペレット表面全体に数 $\mu \mathrm{m}$ 程 度の微細なエミッ夕粒子が一様に分散した電子放射層が形成 されており，エミッタの構成元素である $\mathrm{Ba}, \mathrm{Sr}$ および O が均 一に分布している. また，電子放射層 (Fig.13 SEI 像の矢印の

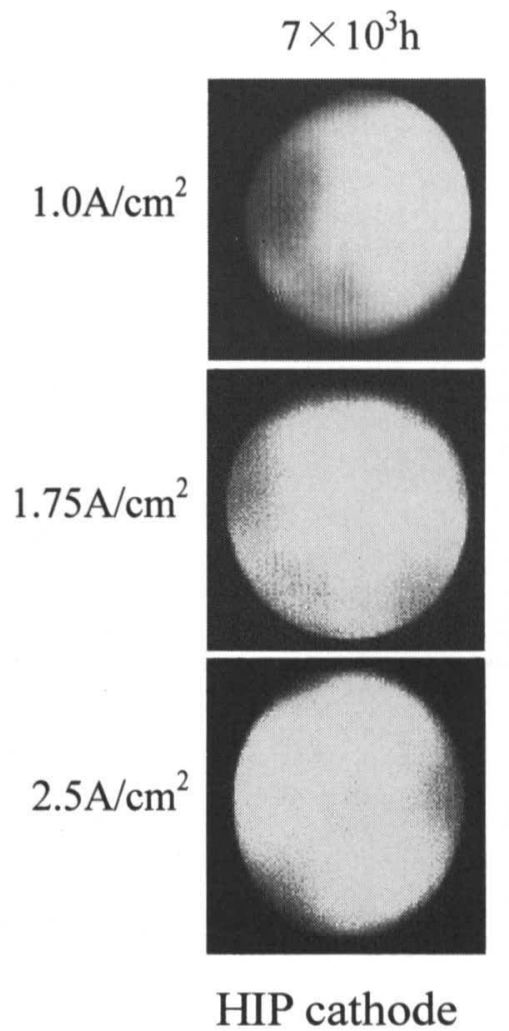

Fig.10 Photographs of cathode image of HIP cathodes in life test, operating at different current density after $7 \times 10^{3} \mathrm{~h}$.

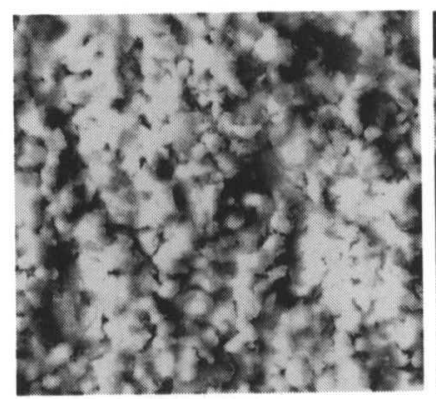

before life test

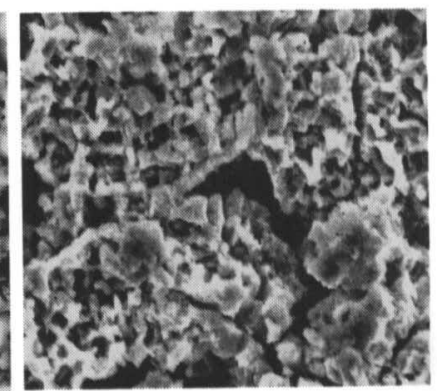

after life test $\overline{10 \mu \mathrm{m}}$
Fig.11 SEM photographs of surface of HIP cathode pellet before and after high current density life test for $1.5 \times 10^{4} \mathrm{~h}$.

領域)は, $10 \mu \mathrm{m}$ 程度の均一な厚みである.一方, $1.5 \times 10^{4} \mathrm{~h}$ 経 過後は, 電子放射層のエミッ夕粒子は微細なまま保持されて いるが, 電子放射層の厚さ方向に数 $\mu \mathrm{m}$ の凹凸が生じていて (Fig.13 SEI像の矢印の領域), 一部に Ni が露出し, 寿命試験前 に比へて電子放射層の厚さが不均一になっている. エミッ夕 構成元素のうち $\mathrm{Sr}$ は凹部からは檢出されず, 表面の凹凸を反 映した SEI像に対応した分布をしている．しかし，Baは凹凹 と無関係に全面に分布し， $O$ も均一に分布している (Fig.12). 寿命試験 $1.5 \times 10^{4} \mathrm{~h}$ 経過後の電子放射層の変化にもかかわらず 


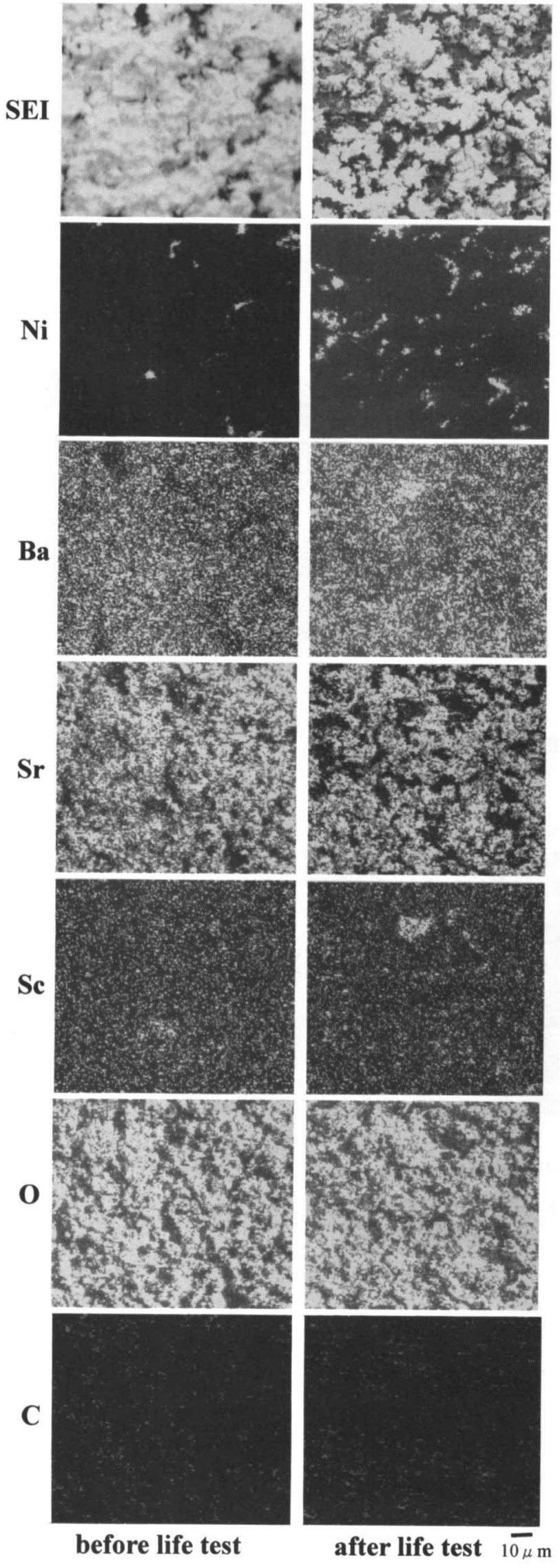

Fig.12 EPMA images of surface of HIP cathode pellet (a) before and (b) after high current density life test for $1.5 \times 10^{4} \mathrm{~h}$.

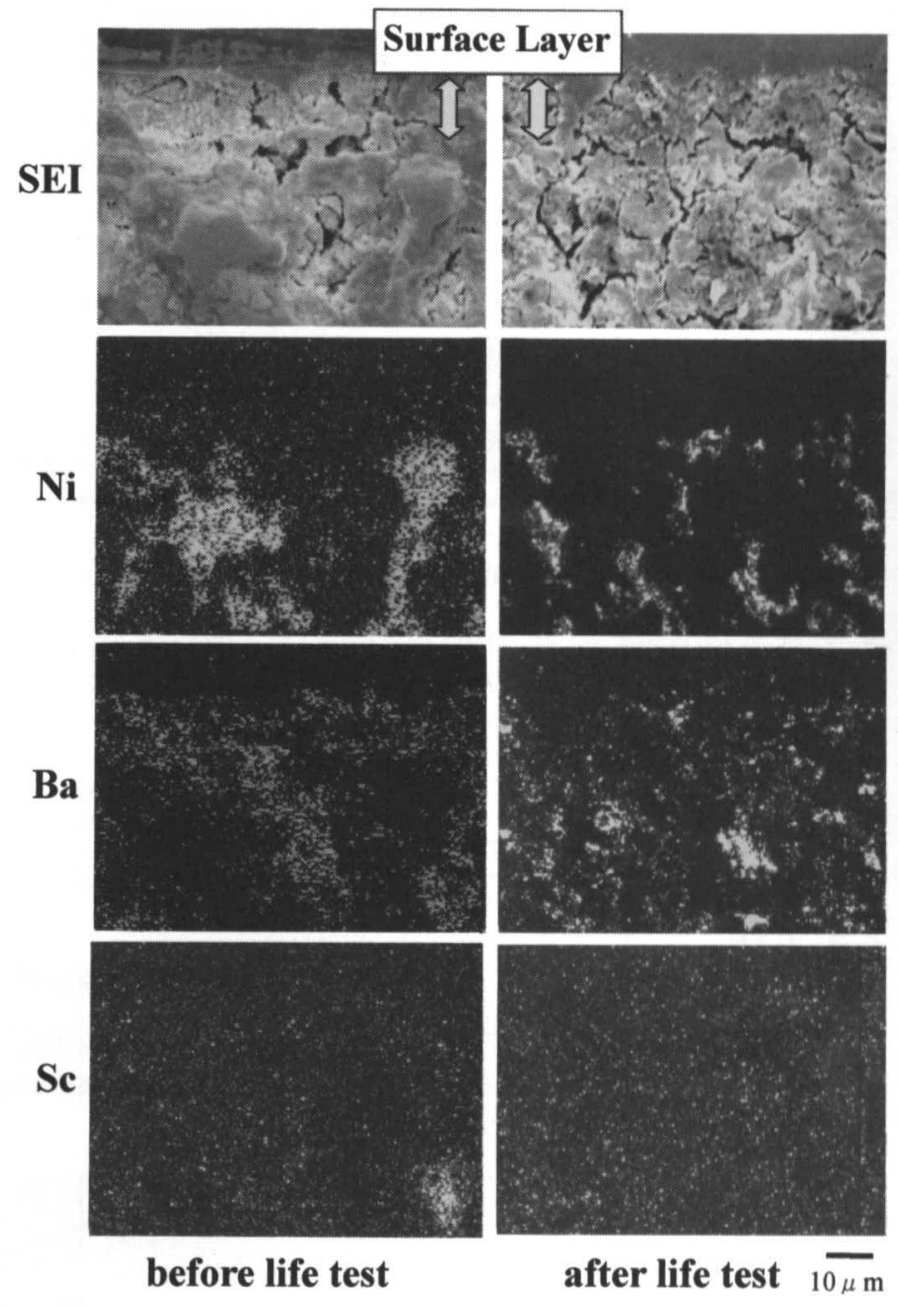

Fig.13 EPMA images of pellet cross-section of HIP cathode pellet before and after high current density life test for $1.5 \times 10^{4} \mathrm{~h}$.

電子放射特性の低下が生じないのは(Fig.5), Ba がペレット内 部から供給されて $\mathrm{BaO}$ が表面全体に分布しているためと考え られる. $3.5 \times 10^{4} \mathrm{~h}$ 経過後, MIk が試験前から約 $20 \%$ 低下した のは, 電子放射層の凹凸が著しくなり, $\mathrm{Ba}$ の不足が生じてい るためと推察される.

これらの結果から推測される寿命試験時における HIP カ ソードの電子放射層の経時変化を Fig.14 に模式的に示す. 寿 命試験前 (a)は電子放射層 (Ba, Sr, Ca)O がペレット表面全体を 覆っており, 電子放射に不可欠な $\mathrm{BaO}$ はペレット表面全域に 分布している. 試験時間の経過とともにエミッタが不均一に 蒸発するため, $1.5 \times 10^{4} \mathrm{~h}$ 経過時 (b) において, ペレット表面 の電子放射層の被覆面積が減少し, かつ, 層の厚み方向に凹 凸生じる。しかし, 電子放射層の欠落しているペレット表面 領域にも電子放射層またはペレット内部から供給された $\mathrm{BaO}$ が分布するため, ペレット表面全体での電子放射に十分な Ba 濃度が供給され，良好な電子放射特性を維持しているものと 考えられる。 


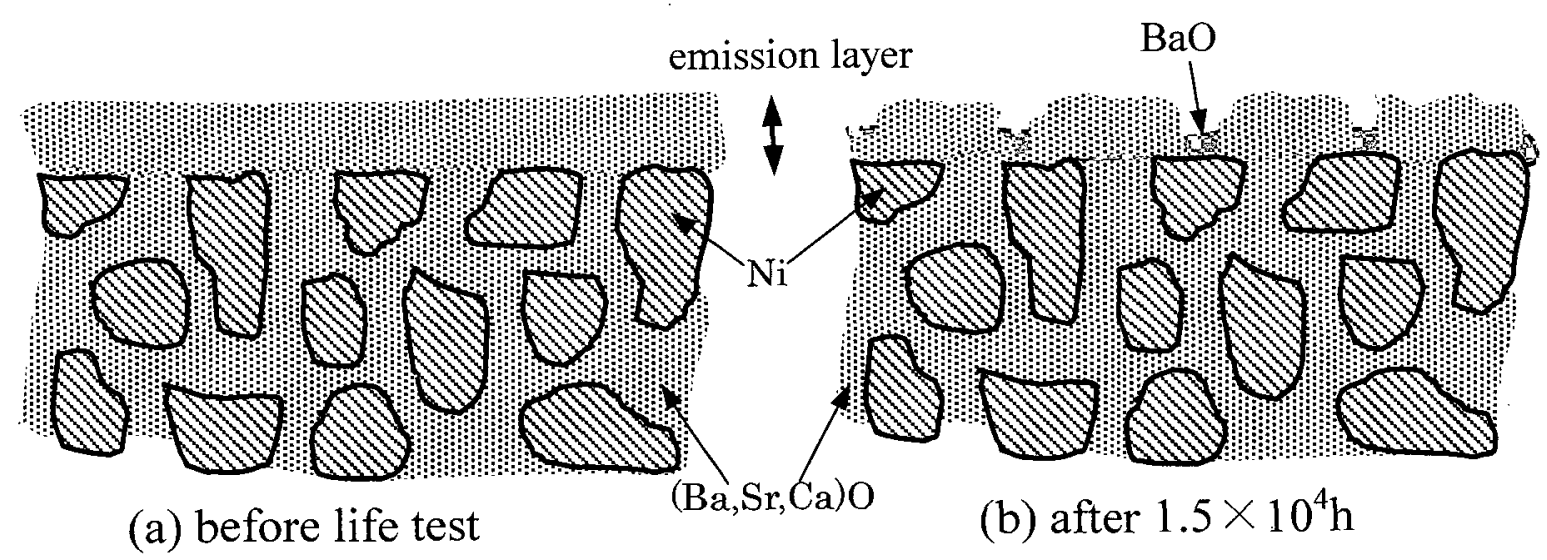

Fig.14 Structure change of cathode pellet in life test for HIP cathode.

\section{4 結言}

低温動作HIPカソードの高電流密度下での寿命試験を行い， 最大カソード電流の測定，カソード像の観察による電子放射 特性の評伍および電子放射層の組織変化を観察し，以下のこ とが明らかになった。

(1) 平均電流密度 $3 \mathrm{~A} / \mathrm{cm}^{2}$ の大電流密度加速試験における $1.5 \times$ $10^{4} \mathrm{~h}$ および $3.5 \times 10^{4} \mathrm{~h}$ 経過時点で最大カソード電流の低下 率がそれそれ3\%末満および20\%末満の優れた寿命特性が 得られた。

(2)この試験における $1.5 \times 10^{4} \mathrm{~h}$ 経過後のペレット表面に形成 された電子放射層には凹凸が生じて厚さが不均一になり， 一部に Niが露出した. ただし，Baがペレット内部から供 給され続けて $\mathrm{BaO}$ が電子放射層全面に分布し，電子放射 特性を維持していた。

(3) 管球の実動作条件に近い3極管動作回路を用いた平均電流 密度 $1.0 \sim 2.5 \mathrm{~A} / \mathrm{cm}^{2}$ の実動作過負荷加速試験における $7 \times$ $10^{3} \mathrm{~h}$ 経過後においても，動作初期の最大カソード電流およ びペレット表面の電子放射の均一性を保持しており,高電 流負荷に対して優れた寿命特性を有していた。

\section{文献}

1) J.L.Cronin: "Modern dispenser cathodes", IEE Proc., Vol. 128, Pt. I, (1981)19-32.

2) 遠藤順, 佐々木紳二, 中川智: "CRT 用含浸型カソード ", 信 学技報, EID89-75(1989)7-12.

3) T.Sugimura, M.Narita, R.Takeda and T.Hirai: "A Newly Developed HIP Cathode Sintered under High Temperature and High Pressure", Proceedings of The 6th International Display Workshops (IDW'99), Sendai, ITE and SID, (1999)533-536.

4) 杉村俊和, 平井太郎, 成田万紀, 武田良一: " 高温, 高圧下 で娔結された新開発HIPカソード", 映像情報メディア学会 誌 , 54(2000)1203-1207.

5）杉村俊和, 田中義之, 水上正彦, 加藤昌宏 : "HIP 法による 低温動作力ソードの作製",粉体および粉末冶金, 48(2001) 237-243.

6) 杉村俊和,田中義之: "HIP 法による低温動作カソードにお けるエミッ夕の熱分解・枯化と電子放射特性",粉体および 粉末治金 , 48(2001)915-921. 